\title{
THE RISE OF FEDERAL JUDICIAL SUPREMACY IN THE UNITED STATES.
}

\author{
PART II.
}

We next find before the bar of the Supreme Court that picturesque and always interesting character, Aaron Burr. The story of Burr is a melancholy episode in our history, quite familiar in its details. Aaron Burr was a man of unusual parts, a man of broad culture, and a man of profound influence in his day and generation. That he who had held the second honor in the land, should be a subject for the rigor of that clause in the Constitution which says that "Treason against the United States shall consist only in levying war against them or in adhering to their enemies, giving them aid and comfort," was most unprecedented in history. It is well that this law is so clear and unsusceptible to variation of construction. The court for the first time expounded this truth, and drew the line between actual war and a conspiracy to precipitate war with treasonable intent. In this memorable case Burr was his own best counsel, although there were two of the first minds in the profession engaged. Burr was a brief speaker, but adroit and thorough. In his trial he rose almost superior to himself, so calm, so respectful, yet self-reliant and skillful. A man worthy of the magnitude of his alleged dream of conquest and power. The case simmered down to a question of evidence, whether collateral testimony was admissible to show that Burr, though hundreds of miles away, was, nevertheless, connected with the objectionable transactions on the Ohio River at Blennerhasset.

The court held such evidence irrelevant, and in the words. of the eloquent Wirt, Marshall stepped in between Burr and death. This result was not satisfactory to either side. A technicality seemed to have averted punishment, or defeated vindication. The cloud, unlifted, shadowed the subsequent career of Burr, but seems not to have shortened his days; he 
lived until 1836 when, at the age of eighty-five, he died on Staten Island, practically alone. If this unfortunate man was innocent, it is a pity the judgment of the court should have been denied in confirmation of the fact. It has been thought the court lacked moral courage, and waived the final issue, but the record of those superb jurists will hardly support such a view. The court was now about to enter upon its noontide course. Mr. Justice Joseph Story, the jurist historian, at the age of thirty-two, succeeded to the Supreme Bench in place of Justice Cushing who had died. The death of Justice Chase had deprived the court of another of its early lights and his successor was Gabriel Duval, of Maryland, appointed by President Madison, a man of sterling morality but hardly equal to the superb Story, with whom his Supreme Court labors were begun.

The court was quite even at this time, all the way through. The Chief Justice was decidedly the dominating spirit, but his coadjutors were all men of strength and integrity, and were worthy to preside in the presence of that illustrious bar, composed of men of the highest talent and luminous ability, the like of which has probably never since flourished in this country. It was at this time that William Pinckney returned from his mission to Europe, and became Madison's AttorneyGeneral. He was an international lawyer, both of experience and of natural talent, and the character of the law then under consideration, that concerning prize and admiralty causes, was so happily suitable to his education as to open a career unexcelled in brilliancy by the record of any member of the American Bar. With this legal Ajax, to use the word of Story, stood Horace Binney and Luther Martin, Daniel Webster, William Wirt, Henry Clay and a score of others whose labors have so justly illuminated the Bar of the United States.

To one of these must be paid, at least, a passing tribute, passing, because I dare not dwell too long in the presence of such inspiring worth, yet, with this pattern of intellectual manhood, with one who in his prime was cast an exile upon a foreign shore, who, amid affliction and sorrow, made proud his asylum 
-with such it is well that the present generation should still be familiar-if only in name; this was the mighty Emmett who distinguished himself in the famous case of the Nereide.

That such as these should live and die, leaving in their wake no trace more enduring than that left by the effulgent comet which darts meteorically from beneath the horizon, is one of the most melancholy incidents of ephemeral human effort.

Such is the fate of all forensic genius. As William Wirt remarked, in speaking of this subject, "What should we have known of Hortensius but for Cicero." Which remark brings us back to the consideration of the great jurist writer, Story, from whose tireless pen flowed the accumulated erudition of years of ceaseless toil. No wonder, when the vastness of his range is considered, that some of his work should show imperfection. Opinions, reviews, text-books and various other productions covered a prodigious field, and if there was an impatience of minute accuracy apparent in one work, it was made up by the valuable contribution in another. Criticism has been advanced both favorably and otherwise, which is a condition not to be looked upon as in the least disparaging to Story, but is an evidence of a healthy intellectual watchfulness, and if some one has found the few flaws in the vast fabric, so much the better for us, and this is not to be looked upon as remarkable when so much ground was covered in one triumphant march.

Story was a New England man, a Democrat, and, from his earliest professional days, a man of ardent industry. He was born in 1779 of distinguished parentage, and was graduated from Harvard in 1798 . It is a point worthy of note to observe how, among very unfavorable political surroundings, he rose to a position in society of prominence early in life. The law reports are full of his notes, and his text-books are standard works that will probably be authorities for many generations to come. Of all the American jurists he is the one who was most familiarly known. He had wide correspondence and innumerable acquaintance, which may or may not have been the 
consequence of his mental pursuits and, perhaps, was due to an agreeable personality.

At times this man outdid his superior in the preparation of his learned opinions. He produced, on the occasion of the Dartmouth College Case, an opinion which was a masterpiece in its analogies and logical conclusion. Not but that Marshall's views were equally complete, but they were briefand imperinas. for this reason.

The masterful decree of the Federalist needed no appeal to the reasoning of the multitude, but the Democratic Story would share the premises of his judgments with the whole world.

The states, in this case, suffered another blow, and again in the later case of the Insolvent Act of New York, where both retrospective and prospective laws were included in the discussion. The Chief Justice and two of his court dissented from the general opinion, believing that the Constitution covered both classes of law. This dignified custodian of the rights of the American people had next a very delicate question in the case of McCulloch v. Maryland, a singular and wonderfully important constitutional question. The State of Maryland had proceeded to tax a Federal institution, a branch of the United States Bank. When the National Government declared this act void, the State of Maryland declared the United States Act chartering the bank void. The arguments in this case were unusually full, there being an extra counsel on each side. Mr. Pinckney occupied three days in his discussion. In this case the spirit of the court came out in very plain terms. The Chief Justice sealed the Federalistic principles of the judiciary in these words. In speaking of the Federal powers of the government, he said: "Let the end be legitimate, let it be within the scope of the Constitution, and all means which are appropriate, which are plainly adapted to the end, which are not prohibiled, but consist with the letter and spirit of the Constitution, are constitutional." With such views as these do we wonder that this one of our several departments of government has outstripped all others in the race for supremacy-this view in the presence of the roth 
article of the Constitution, which says, "The powers not delegated to the United States by the Constitution nor prohibited by it to the states, are reserved to the states respectively or to the people." This renders the scope of the powers, so far as the end is concerned, quite a delegated and limited power. Yet, following the view of the court, we find that the means are not within the limits prescribed for the ends, and the powers of government for adopting means in carrying out delegated ends, cease to be the circumscribed variety of powers characteristic of a government of delegated powers. Any legitimate means not prohibited are legal. This is a broad view. All that is not delegated as to actual powers of government belong to the states or the people. All that is not prohibited as to the means necessary to carry out these powers of government belong to the Federal government, and it is not for the people or the states to question such means, provided they are consistent in the eyes of the Federal judiciary with the powers delegated. Such a means was a bank, and its legality was fixed.

To determine on what ground the decision of the court must rest, and what the proper view of the court should be as to the states' rights in taxing national banks, was a difficult task. So far the states' taxing power was unlimited, it was one of the prerogatives of sovereignty that had never been delegated. What was to prevent this unrestrained force from extinguishing any or all of our institutions, national or otherwise? At a later period it was demonstrated how easily the state banks could be wound up by a judicious exercise of the taxing power in the hands of the United States, and it was to prevent such results that this case proceeded to declare the limits to this state sovereignty, without the semblance of a constitutional provision, save such as must constructively be recognized ere the nationality of our Union be undermined. Marshall perceived all this and acted accordingly, and, following the advantage thus gained, we can imagine the United States exercising the very power denied the states, to the extermination of every vestige of a state institution, so long as the Republican form of government be unimpaired. So 
far the important rulings had been made while interpreting the letter of the Constitution, but this time a vast slice had been taken from the states' rights, by a judgment based on the spirit of the law only.

In 1812 , the death of Justice Livingston made vacant the seat about to be occupied by Smith Thompson. This man, born and bred in the atmosphere of astute and learned lawyers, was destined to figure at the bar of New York when it was adorned with the most cultivated and brilliant talent that has ever been the boast of any state. From among these lights he was elevated to the State Supreme bench where he sat for seventeen years. His promotion to the United States Supreme Court, which occured after he had been Chief Justice of New York and Secretary of the Navy, found him eminently well fitted to be associated with those who were engaged in constructing a nation. Justice Trimble, who succeeded Todd in 1826 , was also a man of unusual ability, and he, too, might have been Chief Justice of Kentucky, as Thompson had been of New York, had he not twice refused the honor. His regard for the National Judiciary, however, would not allow him to refuse a district judgeship, from which, nine years later, he rose to the highest court. His promising services were cut short after a very brief time, and he was followed by John McLean, of Ohio.

The court entered, in 1824, upon a series of decisions in regard to the infringement on the part of the states' legislation of some of the powers expressly granted to the Congress. These were cases of interstate and foreign commerce. Necessarily these decisions were Federal, and it is only consistent to suppose that the subsequent cases permitting the states to exercise authority in instances where no national law has been passed, or where they fail to reach, would not have resulted as they did had not the complexion of the Supreme Court been reversed.

The next decision adding a link to the chain of Federal development was pronounced against the State of Missouri, which had been summoned to the bar of the United States Court to answer for having emitted bills of credit. This state 
proposed to set up a loan office where certificates were issued in small denominations secured on certain public lands. Had this been a loan pure and simple, it would have been a legitimate proceeding, but the Supreme Court, reversing the State tribunal, decided that the certificates were bills of credit, and illegal.

It was never attempted to deny to the states the right to expound their own constitutional and legislative acts, nor did the Supreme Court, during the days of this memorable incumbency, arrogate common law jurisdiction, but so far as the spirit or letter of the supreme Federal law would permit, and wherever the jealous watchfulness of the judiciary could perceive, nothing was lost that might serve as a stone in the bulwark of Federal centralization, and the component states were met on every occasion where there was the slightest possibility of their assuming a privilege dangerous to the nationality.

Towards the end of this period of Marshall and his court, there were two more changes in the personnel of the bench. Justice Washington completed thirty years of continuous labor and almost accomplished as long a career as Marshall. $\mathrm{He}$ was followed by Henry Baldwin, of Pennsylvania, who, like Justice Wayne, belonged more to the period of Democratic Taney than to this session of centralization. Wayne succeeded to the bench on the death of Justice Johnson, and thus an entirely new bench replaced the one which was sitting in the early days when Marshal commenced his long and arduous course. Although some of these pioneers had struggled long, ere their days were done, their vigorous chief saw them one by one gathered to their reward, and after the complete renewal of the court, and another generation had commenced, he lay down his burden of eighty years with his mental powers unimpaired and his personal influence still dominant.

The court that followed under the learned lead of Taney was Democratic in its tendencies, but the bark of Fedralism was too far advanced on her course to be overhauled, and the subsequent turn of events only combined to speed her course.

It was a bold stroke completed, and while easy to-day to 
realize the necessity of a strong national court, when the light has been turned on by the artistic hand of the master spirit Marshall, yet how many can appreciate how difficult was the task of initiating the people in the first principles of Federal judicial power?

This court striding boldly through the new forest of national complications, struck down the giant trees with the same ease as it swept aside the entangling underbrush of smaller difficulties. They had cleared up the question of implied, as well as expressed powers of Congress; they had checked the legislatures of the states in their efforts to control Federal powers ; to tax Federal agencies ; to emit bills of credit; interfere or regulate commerce, among themselves or with Foreign Nations; they had rebuked the defiance on the part of the state judiciaries of their own decrees and had set up the supremacy of the National Government in the right to tax, to establish banking systems, and to pre-eminence and preference in payment of debts of creditors. The Legislature of the nation had likewise met its Master in the indomitable Marshall, nor was the Executive exempt, although that department was incumbered at times by the most opposing influences backed by such sturdy dispositions as those of Jefferson and Jackson. Not one step, however, was added to the power to take the initiative, and the case of Worcester $v$. Georgia, shows how a recalcitrant defendant was free from any other than moral suasion. Enough, however, had been accomplished and the power which was left by this remarkable court as a heritage to those who have come after it, is at once an incalculably valuable and tremendously dangerous trust. With such a pure, learned and able judiciary, as that with which the United States has heretofore been blessed, power is our prosperity, advancement and happiness; but let corruption creep beneath this ermine mantle and we are lost.

Weakness, ignorance or vice, clad in the raiment of such a stupendous power, would precipitate poverty, deterioration and sorrow, withering our nationality like a blast from the infernal. As has been said, the National Judiciary has been constitutionally lifted aloof from the fickle and ephemeral 
fancies of the populace, but this advantage is not without its accompanying danger.

It is not always well that the people should be denied a quick and prompt opportunity of ridding themselves of an unworthy servant. That it is impossible to deceive the entire multitude at all times is the secret of the superiority of popular government, and it is often well that the general voice should be heard. The Supreme Court is far from this voice, and it is to be hoped that the noble past will be emulated in the future, and there will be no necessity to fetter our independent judiciary with the heavy political chains that bind the every movement of the servants of the state in the other departments. The Supreme Court to-day, while doubtless not so imposing as in its "Golden Age," is not one degree less respected nor less worthy of the confidence of the people. Its decisions are fraught with finer distinctions, and where its predecessor had but to gather in the first abundant fruits, our contemporary judges have to glean what is left after a century of litigation. The acute intellect of the modern jurist has a more onerous task, protecting the rights of this greater nation, than was imposed upon those who formulated the fundamental principle under which this generation has found prosperity, hence it is well that we scrutinize fastidiously the nominations of our Chief Magistrate, and it behooves the advising Senator to look diligently before he concur in the appointment of a Justice of the Supreme Court.

Philadelphia, September, r8g8.

Thomas Kilby Smith. 